(10)

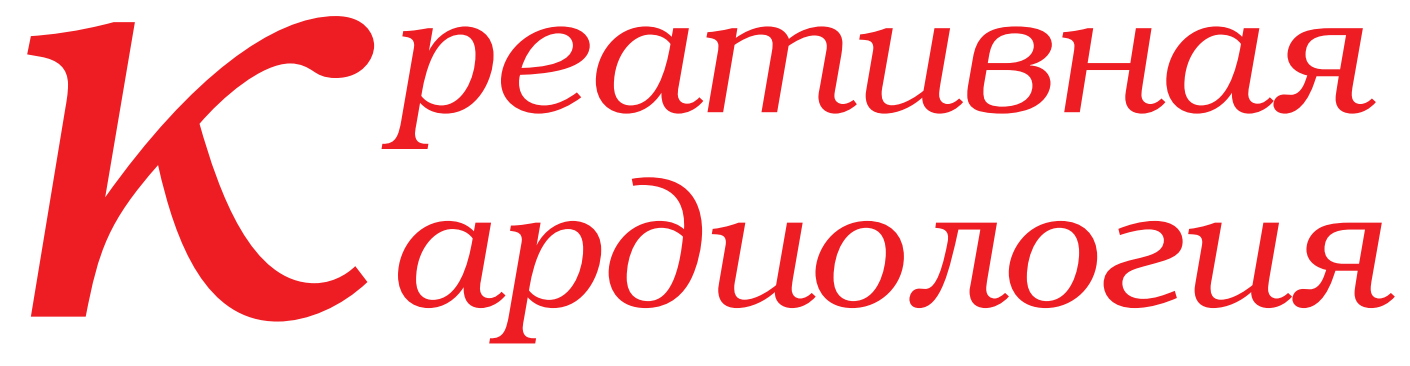

\title{
Creative Cardiology
}

$$
\begin{gathered}
\text { T. 13, № } 2 \\
2019
\end{gathered}
$$

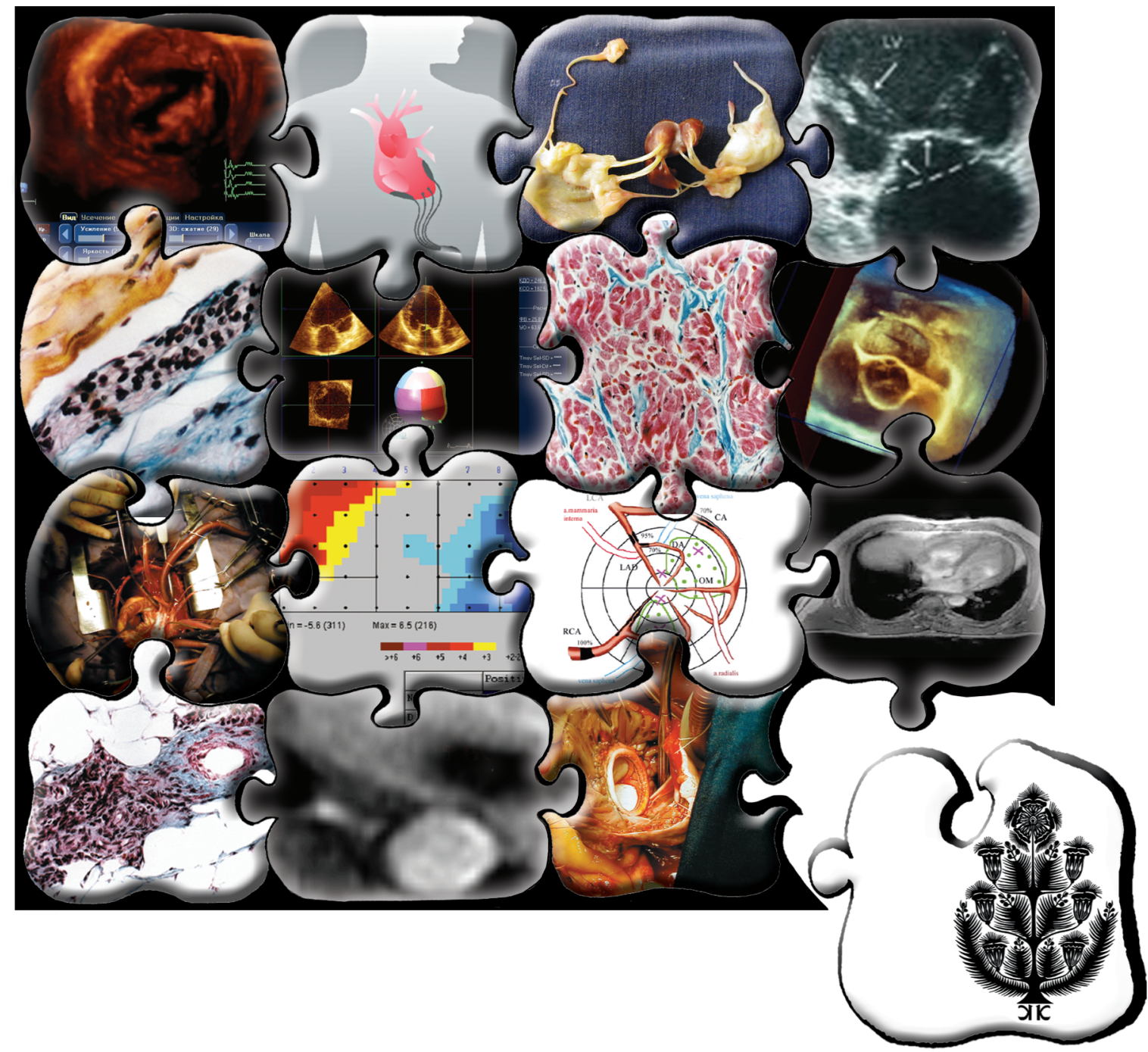

